\title{
Bilingual Strategies in Fourteenth-Century Latin Sermons from Catalonia
}

\author{
Lidia Negoi*
}

This article discusses the phenomenon of bilingualism in medieval sermons by focusing on one of the most understudied areas of sermon studies - fourteenth-century Catalonia and Aragon. Specifically, I concentrate on Latin sermons, which remain largely underexplored, partly due to a certain historiographical bias that favours "national « languages over Latin. The main focus is on Dominican sermons from the Aragonia Province (which included Catalonia and Aragon).

The main argument is that bilingualism in sermons was an editorial communicative strategy acquired and developed in an educational context, i.e. in how language was approached and learnt by bilingual users. To make my case, I first discuss the language training of the Dominicans from Aragon and briefly review some bilingual grammatical works in order to place the bilingualism of the sermons within a wider context of written (and spoken) multilingualism. Second, I address bilingualism and code-switching in sermons by analysing texts in which Latin is the matrix language, the most common type of sermon evidence preserved from this area. As in better studied areas, such as France, England, or Italy, the linguistic intermingling in fourteenth-century sermons from Catalonia covers all types of "macaronicity«, as categorised by Siegfried Wenzel. Thus, the paper will add to current debates that seek to understand medieval bilingualism (written and spoken) as a late medieval Europe-wide phenomenon by discussing hitherto unstudied and underexplored evidence in manuscripts that remains largely unknown to scholarship.

Keywords: bilingualism; code switching; macaronic sermons; Catalonia; Dominican Order; Nicholas Eymerich; Guillelmus Simonis

Mixed-language sermons have always intrigued scholars of medieval preaching. Linguistic promiscuity has been variously valued, whether positively or negatively, in the study of sermons. More recently, the liminal space mixed-language sermons occupy has been approached on its own terms from the perspective of multilingualism.

* Correspondence details: Lidia Negoi, Institute for Medieval Research, Austrian Academy of Sciences, Hollandstraße 11-13, 1020 Vienna, Austria; email: lidia.negoi@oeaw.ac.at. 
The dynamics of the coexistence between languages in late medieval sermons have yet to be more comprehensively explored. Some geographical areas are better researched than others, though certain gaps remain in the study of sermons in a broader time frame. Additionally, the focus on either Latin or the vernacular in isolation has tended to obscure their complex relationship. The fact remains that sermons written down in Latin as a matrix language constitute the vastest body of evidence of medieval preaching from the thirteenth through the fifteenth centuries. ${ }^{1}$ This paper focuses on Latin sermons with vernacular insertions from fourteenth-century Catalonia, one of the least explored areas of sermon studies both in terms of the regional and the chronological span, as the fourteenth-century preaching has not been as systematically researched in comparison to the thirteenth and the fifteenth centuries. ${ }^{2} \mathrm{My}$ aim is twofold: to discuss unpublished, little-known material, and to add to current debates about the nature of the relationship between Latin and the vernacular in written sermons.

Latin sermons with various vernacular insertions have been variably viewed as expressions of multilingual communities and individuals (those who produced them and their audiences), as proof of poor linguistic competence in Latin, as literary constructs, or as symptoms of broader cultural shifts that influenced the development and standardisation of the vernaculars. ${ }^{3}$ The motives of authors and scribes who wrote down bilingual texts and the nature of the various types of linguistic mixtures remain the most debated aspects of multilingual sermons. Scholars have noted two broad forms of vernacular insertions. On the one hand, there is a "controlled « kind, such as terms, translations of the biblical thema, authorities and proverbs, usually signalled by markers such as "vulgariter", »in vulgari sic", which are visually delimited on the manuscript page, e.g. as separate verses, blocks, and so forth. On the other hand, there is a more "unpredictable« type in which the vernacular interferes inside or between sentences in no discernible pattern. Scholars largely agree that the "predictable» type of bilingualism was motivated by the need of authors/scribes to have a vernacular translation at hand either for themselves or for other readers. This type can be observed in "models" and commissioned collections that enjoyed a certain regional circulation, e.g. sermons destined as didactical material for studia. However, the mixture that appears indiscriminate within a predominantly Latin text has been connected to personal books and notes that were not meant for wider dissemination and, thus, it usually appears in unique manuscripts. ${ }^{4}$ This mixture is the object of ongoing debates. While some argue that this type of language alternation reflects the bilingualism of the writer of the text and constitutes a written habit, and

1 See the essays on vernaculars and Latin in Kienzle, Sermon; the most recent overview of the developments in sermon studies is Thayer, Medieval sermon studies.

2 See Catalán Casanova, Predicació cristiana, which concentrates on vernacular preaching; Negoi, Dominicans, Manuscripts, and Preaching, for Latin sermon production.

3 d'Avray, Preaching of the Friars, 90-95; Bériou, Sermons latins, especially 382-386, and Bériou, Latin et langues vernaculaires; Delcorno, Language of the preachers; Muessig, Vernacularization.

4 For instance, Delcorno, Language of the preachers, 50-51, on thirteenth- and fourteenth-century material from Italy; Bériou, Latin et langues vernaculaires. 
hence does not mirror actual delivery, others contemplate the possibility that sermons in which Latin and the vernacular continuously intermingle could have been preached as such for specific bilingual audiences, e.g. academics. This line of enquiry has more recently been followed by Siegfried Wenzel, who views the "macaronic « kind of mixture as different from the more "controlled" types because they performed a different role in the discourse. ${ }^{5} \mathrm{He}$ thus proposed a taxonomy of bilingual sermons by function. These »ideal types « overlap the two broad kinds mentioned, with the difference that the "controlled« mixtures are split into two categories: A, in which vernacular items (e.g. proverbs, glosses, translations of authorities, etc.) function either to explain Latin terms or reinforce certain ideas, and B, in which the vernacular appears in the structuring devices and has a crucial bearing on the discourse. The third, C, is the seemingly unpredictable language mixing, i.e. intra- and intersentential. This type could, in Wenzel's view, be a reflection of speech and evidence of the "code-switching " strategies of bi(multi)lingual speakers. ${ }^{6}$

One of main objections to Wenzel's approach concerns his equating of the written text with a representation of speech rather than a writing strategy of authors and scribes. ${ }^{7}$ Furthermore, Wenzel's application of code-switching to an imagined speech phenomenon has been challenged by the historical linguist Herbert Schendl, who advocates instead that all types of linguistic alternation and mixture in texts (sermons included) should be considered code-switching and should be viewed as evidence of a process of written vernacularisation throughout later medieval Europe. Likewise, Schendl is critical of Wenzel's taxonomy and notes that the ascribed roles of the vernacular elements in each type are not so clear-cut either in their roles in the sentence or in the structure of the discourse. ${ }^{8}$ Other scholars, though, do not fully reject such a possibility, and recommend a "non-dogmatic « approach when dealing with mixed sermon texts of all kinds. ${ }^{9}$ The debate on code-switching of all kinds as written strategies in relation to actual speech remains open, nonetheless. Wenzel's thesis might not convince everybody and his categories might not capture or explain the varied spectrum of linguistic mingling and motivations of sermon writers in medieval England as elsewhere in Europe. Much still remains to be understood about the contexts in which bilingual texts were generated and transmitted in the various linguistic areas of late medieval Europe.

This article builds on these debates and takes multilingualism in sermons as a written, widely shared, practice. It adopts code-switching as an analytical category that applies to all kinds of Latin-vernacular sermons and focuses on texts produced by the Dominican friars from Catalonia. I argue that bilingualism in Latin sermons with Romance insertions from this linguistic area was a written communicative strategy and convention rooted in educational contexts and practices of the teaching and learning of the language arts. ${ }^{10}$ Therefore, I

5 Wenzel, Macaronic Sermons, 17-30; add Delcorno, Language of the preachers, 48-50.

6 Wenzel, Macaronic Sermons, 113-123, also for a synthetic view and criticism of literature on the language of sermons distinguished by audiences.

7 For instance, Fletcher, Written versus spoken; Schendl, Code-switching, 160.

8 Schendl and Wright, Code-switching in early English, and Schendl, Code-switching.

9 Bériou, Latin et langues vernaculaires, 206.

10 Note that I will use Romance as a generic term and Catalan for a more specific context. Needless to say, sources refer to »romancium «, not to »Catalan«. 
examine Latin sermons with vernacular elements on their own terms as written evidence of potentially discursive practices in either Latin or the vernacular. While I do not discard the idea that bilingual sermons could be uttered as such in school exercises, I disagree with Wenzel's premise that the presence of vernacular mixing is fundamentally connected to a spoken phenomenon. To understand these practices, I explore them in a broader context: didactical, codicological, the intended purpose of the work, as well as the textual and discursive context in which bilingual code-switching occurs. The argument will be deployed as follows. Firstly, I ground the material in a historical and didactical setting that informs the further discussion by outlining the role of language education in Dominican schools and in a broader context. Secondly, to understand better the nature and purpose of code-switching in their sermons, I discuss in detail two sermon manuscripts by two fourteenth-century Dominican authors by contextualising bilingual alternation and code-switching in the discourse, i.e. in the relation between the switch, the structure and the message of the sermon. Thirdly, by drawing on the analysis of these two cases, I conclude with a section that aims to integrate the examples in a larger diachronic perspective of bilingualism in sermon production from Catalonia and beyond.

The Dominican Province of Aragon, which came into existence in the early fourteenth century, was a multilingual unit that comprised three linguistic areas and nationes: the Catalans, the Aragonese and the Navarrese. ${ }^{11}$ A Dominican friar would join a convent closest to home and it was in his native language area that he would eventually preach in public to larger audiences. While theology was central to the work and education of the Dominicans, a young friar also needed to gain mastery of language in a broad sense. Preaching in Latin and the vernacular was part of the practical training, as future preachers regularly had to give "mock" sermons in both languages in their convent before getting a licence to preach in public. ${ }^{12}$ Probably, this practice was supplemented with more theoretical lessons on how to compose a sermon according to the requirements of the arts of preaching. Yet, this was only part of the process of learning that presupposed previously acquired skills in Latin and the vernacular.

The language training of the Dominicans and the importance of the language arts to their office have not been much studied. As stipulated in their regulations, the entrants and novices were expected to have a basic and working knowledge of Latin and grammar before profession, but normative sources remain vague and unclear beyond that. ${ }^{13} \mathrm{~A}$ detailed examination of the language education of the Aragonese friars is beyond the scope of this article.

11 These areas overlapped with the territories of the confederate kingdom of Aragon and the kingdom of Navarra; from 1324 the Catalan natio included the regions of Catalonia, Valencia, the Balearics and Sardinia. I use Aragonese to denote affiliation with the province; in specific linguistic contexts, it means the Romance spoken in Aragon.

12 Mulchahey, "First the Bow «, 184-193, for the training of the preachers; the Acts of the General Chapters from 1346 (reinforced in 1347), for instance, instruct priors to license only those who had "frequently" preached in Latin and the vernacular in the chapter house, in Acta capitulorum generalium Ordinis Praedicatorum 2, ed. Reichert, 310.

13 Mulchahey, "First the Bow«, 79-129. A very brief outline of a friar's early career: pre-postulants received basic education in Latin, if they had no knowledge of it, and religious instruction; as novices, they would continue with religious and doctrinal education and Latin and grammar, if necessary. As newly professed friars, they would study theology in the convent schola for several years and, at the same time, take specialised courses in grammar (in Aragon), logic and philosophy. Future lecturers would take more advanced theology at the provincial and general studium of the province and a minority (the future Masters of Theology) studied in a general school of another province and at Paris, the highest Dominican studium. 
Nonetheless, a brief preliminary discussion is necessary for my case of bilingualism as originating in school. My hypothesis is that advanced bilingual abilities were gained in the teaching and learning practices of the grammar studia and to a certain extent in the logic courses, which, like philosophy, were informed by theology. Circumstantial evidence and a reading of sources in a broader context will bring some clarity on this matter. ${ }^{14}$ This discussion is therefore relevant for the main argument since exploring language training as well as reviewing some examples of bilingualism in texts other than sermons, i.e. grammatical works, helps us to understand better how the bilingualism in sermons is related to a set of acquired linguistic skills and strategies.

The grammaticalia (the grammar studium), typical for the Province of Aragon, were schools of advanced grammar rather than remedial Latin courses for novices and pre-postulants, as has been suggested. ${ }^{15}$ We do not know the curriculum, but revision of the fundamentals was likely part of the course; in that sense, they could be remedial. That they were advanced language courses is also suggested by the fact that most teachers were Dominicans who had already studied logic. ${ }^{16}$ Besides, Dominicans in Aragon were not alone in organising such advanced courses, as other orders, such as the Franciscans, had similar arrangements. ${ }^{17}$ Certainly, knowledge of Latin and grammar was probably deficient, if one is to judge by the repeated complaints of the Aragonese authorities. When normative sources are specific, it is the spoken Latin and grammatical congruity that was found inadequate for further logic courses. It is perhaps in this manner that one can interpret a 1352 directive that grammar teachers have their students do (»fieri faciant») conjugations, declensions, "proverbia« and

14 Partly discussed in Negoi, Dominicans, Manuscripts, and Preaching, 29-64; I substantially review some arguments. The main sources for Dominican regulations in Aragon are the Acts of the annual Provincial Chapters, preserved in Zaragoza, Bilioteca Universitaria, MS 185 (XVI-XVII copies; incomplete), Acta Capitulorum Provincialium Provinciae Aragoniae. I exclusively refer to this manuscript here, but see also Maierù, Dominican Studia in Spain, for a further bibliography on editions and a discussion of the curriculum in the studia of Aragon.

15 Mulchahey, »First the Bow«, 95-97, mentions grammar schools as external »feeder schools«; Maierù, Dominican Studia in Spain, 7-9. In Aragon, these schools were studia, thus, part of the educational system inherited from before the split from Hyspania (which organised courses of grammar and logic from 1275 onwards). Aragonese regulations are sometimes explicit in that no novice could be received if he needed to take grammar; they had to be competent in reading and "somewhat sufficient« in Latin, in 1321 and 1354, respectively, see Biblioteca Universitaria, MS 185, fol. 105, fol. 254, and fol. 336.

16 The Acts indicate on occasions that priors of specific convents had to find a teacher, but the overwhelming majority were friars themselves, according to the list of yearly assignations to the studia section of the Acts, Biblioteca Universitaria, MS 185.

17 Roest, History of Franciscan Education, 68, noting the recruits were about 14-15 when qualified for logic. That was most likely the case for the Dominicans; the testimonies of two friars from Barcelona and Valencia and the Acts suggest that: Petrus of Arenys and Juan of Mena recorded in their chronicles that they joined their convents at almost 13 (as a novice) and 10 (as a pre-postulant), respectively; took profession at almost 14 and 15 and were assigned to the grammar school of their convents before studying logic. It is hard to believe that neither, especially Juan, had any language training before attaining their legal status of Dominican friars; see Petrus de Arenys, Chronicon, and Johannes de Mena, Chronicon breviusculum fratris Ioannis de Mena, edited in one volume by José Hinojosa Montalvo, 15, 55; for Peter, add Biblioteca Universitaria, MS 185, fol. 311. 
"other rudiments for children«, rather than the teaching of the very basics. ${ }^{18}$ One cannot automatically assume that these exercises implied a lack of basic knowledge since advanced grammar did cover inflections, while "proverbia " most probably meant translating and composing in Romance and Latin, as I will explain shortly. It does not necessarily follow that the young were completely unskilled users of language, but that some acquired a grammatically incorrect Latin (not unusual for bilingual speakers). The emphasis on congruity as a prerequisite for logic also indicates that the language arts built on each other in the formation of preachers. In this light, the study of grammar in the convents of Aragon involved a more comprehensive study of language. Very possibly, students' levels varied and teachers had to adapt accordingly; hence no specific texts were prescribed.

Even if Latin remained the main language of instruction, the vernacular must have been present in the classroom. From the perspective of their main aim - training highly qualified preachers capable of delivering sermons in the languages of their publics -, it would make little sense otherwise. Although friars are usually only connected with the art of preaching, their grammar education must have been very similar to that of students of the trivium and they were, consequently, trained with similar texts and methods. By assuming that, we can place Dominican training in the context of late medieval approaches to the language arts: rhetoric, grammar and logic (dialectics and semantics). Those new methodologies and the texts employed for teaching Latin through the vernaculars changed the manner in which the language arts were analysed and gave rise to advanced, theoretical and speculative grammars, among other developments. The two verse grammars, Alexander of Villadei's Doctrinale puerorum (c. 1200) and Eberhardus of Bethune's Graecismus (c. 1220), became standard manuals for teaching grammar to more advanced learners in a bilingual setting, as these texts and commentaries on them were widely circulated with vernacular glosses in the late Middle Ages. Moreover, it is the commentaries as well as kindred theoretical texts in particular that reflect the interrelation and interdependence between the language arts and the multilingualism of the teaching and learning process. ${ }^{19}$

18 The Acts of the 1352, Biblioteca Universitaria, MS 185, fol. 224; in 1353, the young were signalled, as »in loquendo latinum deficiant notabiliter «, and all friars in a convent were encouraged to speak Latin among themselves at all times, fol. 239; these concerns were reiterated in the following years. Maierù, Dominican Studia in Spain, 9, reads these ordinances as proof that grammar schools taught the very basics of Latin.

19 For convenient syntheses and further bibliography, see Copeland and Sluiter, Medieval Grammar and Rhetoric, especially parts 5 and 6, and Rosier-Catach, Grammar. 
Direct evidence from the Dominicans is scarce, but materials from the Catalan area show that teachers engaged with diverse theoretical texts and methods as elsewhere and, quite importantly, tailored them to the needs of local Romance speakers. We know that the Dominicans in Barcelona already used Doctrinale together with Priscianus minor and texts of logic and Graecismus in the later thirteenth century..$^{20}$ Additional evidence from Catalan archives confirms the friars employed these didactical texts and also indicates that advanced grammatical treatises were widely circulated in the area in the fourteenth century. ${ }^{21}$ Thus, the Dominicans participated in a shared culture of learning and teaching the language arts at formative levels.

Many of the commentaries of Doctrinale in my sample are often associated with other theoretical and applied texts in manuscripts and are multilingual. Their multilingualism ranges from interlinear glosses and bilingual glossaries to organically integrated insertions that can be words (lexical units) or more complex sentences and constructions in the vernacular. ${ }^{22}$ The latter is the most commonly encountered type of language mixing and alternation in commentaries and other advanced grammars, where bilingualism covers a wide array of linguistic matters and occurs mostly in discussions of the parts of speech (partes orationis), i.e. inflections, adverbs, and figures of speech (figurae), where code-switching is more varied. I shall briefly look at several examples of bilingualism that are similar to what one can find in sermons, as the reader will soon discover.

In a manuscript linked to a Dominican and containing a commentary on Doctrinale, Romance is consistently employed in the emphatic use of the definite article, e.g. "lo Petrus" (the Peter), "lo quem « (»the which«), as well as in lessons on nouns as a means of illustration, e.g. the defective of singular, like "los flancs" (»the flanks«). As in other grammars in the sample, including the more theoretical and speculative, in the sections on the parts of speech the vernacular is meant to exemplify rhetorical devices, such as euphemisms ("carientismos"), to be used when "something harsh and stern" is expressed with "gracious words", such as: "Amic negu demanat hac tota bonaventura, sicut dicunt aliqui et nolunt dicere non"

20 Graecismus and Doctrinale with Priscisanus minor appear in two instances in the lending section of the convent's library, edited in Kaeppeli, Dominicana Barcinonensia, 63-64, and 65. The document records the names and books loaned to teachers/advanced students; it covers little of the fourteenth century.

21 I focus on about 20 grammatical manuscripts from Barcelona, Arxiu de la Corona d' Aragó (henceforth: ACA), Ripoll collection (Benedictines), whose medieval codices were gathered from diverse sources through the later Middle Ages, as I point out in Negoi, Dominicans, Manuscripts, and Preaching, 110-111. I only discuss a small sample. The manuscripts are available online at Portal de Archivos Españoles (henceforth: PARES), pares.mcu.es/ParesBusquedas20/catalogo/contiene/1859467 (search terms: "Doctrinale«, "Grecismus«, "gramatica«). Many share features that suggest continuous use by multiple readers, e.g. portable, made of paper, contain glosses, additions of texts, paragraphs, recipes and prayers in Latin and Romance. One such example is a Graecismus (copied 1334), glossed by several hands and owned at one point by a Dominican friar, in ACA, Ripoll, MS 147, note on fol. 97v. More examples to follow; I am unaware of studies on any of the manuscripts cited in the following.

22 For example, ACA, Ripoll, MS 97, Doctrinale puerorum, glossed by several hands in Latin and Catalan, with most Catalan glosses on verbs, nouns and adjectives; ACA, Ripoll, MS 139, "Liber scholae«, bilingual glossary of adverbs, on fols. $5 \mathrm{r}-6 \mathrm{v}$. 
(»[He] needs no friend hence all the good fortune, as some say when they do not want to say no«). ${ }^{23}$ Beyond bilingualism, the manuscript is also illustrative of the employment of logic in grammar, as the figurae part draws heavily on Aristotelian works on language, e.g. On Interpretation, Categories, and other theoretical grammars. Thus, the work might well have been used in a Dominican grammar school; it could function as an introduction to more advanced analyses on language that familiarised students with logic. ${ }^{24}$

That bilingualism was integral to the process of acquiring advanced linguistic skills is further confirmed by more theoretical and speculative texts than this example. One such example is another commentary of Doctrinale that analyses verbs and nouns through modes of signification so as to distinguish between the vocal (literal) and semantic (real) meaning or sense of words, a method associated with the late thirteenth-century "modists «. ${ }^{25}$ Other relevant instances of the vernacular in teaching occur in discussions of syntax, translation or interpretation, and composition ("componere«). ${ }^{26}$ Composition appears to have been of particular concern for teachers who applied the "proverbiandi« technique, meaning paraphrasing, while proverbium could simply mean Romance or a construction illustrated bilingually, as linguists noted in other late medieval grammars from Aragon. ${ }^{27}$ Additionally, this method also involved translation from and into Latin and Romance through "replacing" ("supleccio«), i.e. a circumlocution. ${ }^{28}$ It is thus very likely that the "proverbia " Dominican students were to revise in the grammar studia together with conjugations and declensions meant learning how to compose correctly through the vernacular.

23 ACA, Ripoll, MS 79, Commentary on Doctrinale puerorum by 3 different scribes, marginal glosses by other hands; several owners, of which one wrote that she/he "received this book from Friar Berengarius of the Order of Preachers «, on fol. 185v; articles, for instance, on fols. 167r-v, and the noun on fol. 40r, but other examples throughout; "carientismos" on fol. 165v. Note that the article features in most of the other grammars in my sample. I use Italics to distinguish the vernacular from Latin throughout this article.

24 Aristotle's works on language were part of the logic course curriculum; see Mulchahey, »First the Bow«, 238-252.

25 ACA, Ripoll, MS 154, Commentary on Doctrinale puerorum. For example, when explaining the various significations of "frons" (face or forehead), e.g. "frontispicium " ("frontispice») which can mean "the front face of the church or of another thing " ("hoc frontispicium per frontal desgleya vel alterius rey«), fol. 40r, or when discussing verbs and aspects, e.g.: "lavo idem est quod lavar vel denajar « (»I wash is the same as to wash or to clean«), fol. 180v; other examples on fol. 142r, for instance. There are other multilingual commentaries on Doctrinale and grammars in the Ripoll collection that engage with the modes of signification (modi siginifcandi). On "modists", semantics and the »linguistic turn« in medieval logic, see Rosier-Catach, Grammar.

26 Example of translation in ACA, Ripoll, MS 142, a compilation of theoretical and practical texts by 4 scribes, at fol. 114v: "Hoc idioma transferis per lengatge" ("You translate idiom as language»), in a lesson organised on questions and answers; more examples of bilingualism applied to nouns, verbs, adverbs, throughout the text, fols. 112v-115v. Example of teaching syntax and how to "compose "literally in a Latin-Catalan alternation of each syntactic unit in ACA, Ripoll, MS 191 (a treatise on modes of signification, written 1337), where the sentence »Iste subvenit suo matri« is explained as follows: "Iste/Aquest/subvenit/ha aiudat/suo matri/la sua matre» (»This one helped his mother«), fols. $79 \mathrm{v}-8$ or.

27 Example of a "proverbium« in ACA, Ripoll, MS 142, in another practical grammar (fols. 116r-164r), when explaining how to use the comparative: »Ut si dicatur: La nostra cassa es pus de loriu que la vestra. Componitur sic: nostrum ospicium est ulterius rivum quam vestrum " ("As when you say: Our house is further up the river than yours. You compose as such: Our lodging is further up the river than yours"), fol. 117v; more examples throughout the text as well as in a treatise on "figures", fols. 78r-10ov. For thorough discussions of the proverbiandi method in another grammatical multilingual manuscript from ACA (Ripoll, MS 153) with examples in Aragonese and Catalan, and other late medieval Iberian grammars, see Calvo Fernández, Gramática latina medieval, and Esparza Torres and Calvo Fernández, Grammatica proverbiandi.

28 Examples of circumlocutions abound in these manuscripts; see, for instance, ACA, Ripoll, MS 184, which contains a bilingual text on "suplecciones« and a part of a commentary on Doctrinale. 
To conclude, these examples not only indicate that the vernacular was actively utilised in language schools, Dominican included; it is reasonable to assume that the preachers were trained with the same textbooks and methods: for them, language was a tool. Bilingualism, oral and written, was thus acquired in the grammar courses and further applied in exercises in the logic course, as well as when practising preaching in the convent. Furthermore, many of the issues discussed in these grammars, such as the distinction between vocal and semantic meaning, weighed heavily when rendering Latin terms and phrases or sentences in the vernacular, especially in situations that involved biblical exegesis. Moreover, many of the instances of vernacular employment are quite similar to what one can find in sermons. Multilingual sermons thus reflect the training of friars to be active in two languages: they acquired and internalised rules of writing and delivering speeches both theoretically and practically. The next section will further illuminate these conventions and communicative strategies in sermon collections at different editorial stages.

The first case study is a fourteenth-century manuscript with the Sunday sermons of the Dominican inquisitor Nicholas Eymeric (d. 1399). Nicholas, from Girona, Catalonia, was an accomplished friar who studied and taught in the best schools of his province and order (at Paris) and authored works of biblical exegesis, manuals for students of logic and philosophy, sermons, and polemical works. While most of his writings have survived in manuscripts, few have been studied and edited, his collections of sermons included. ${ }^{29}$

Nicholas' two sermon collections were conceived as manuals for the younger, inexperienced Dominican friars in his native convent of Girona. Both the Sunday sermon collection on the gospels (1366) and that on generic saints, various events and for the dead (1373), are exemplary didactical works composed by an experienced teacher and preacher whose aim was to offer models that served the needs of his brethren. I shall only explore the Sunday sermons here, as only this collection qualifies for a discussion of bilingual code-switching in sermons. ${ }^{30}$

29 For the most comprehensive biography and list of works in manuscripts, see Heimann, Nicolaus Eymerich, 162-218.

30 Nicholas Eymerich, Sermones dominicales (1366) in Sevilla, Colombina y Capitular, MS 123-3-7 (XIV), and Opus sermonum de communi sanctorum plurimorumque eventuum ac etiam multorum diversorum in speciali et omnium in generali fidelium defunctorum, Sevilla, Colombina y Capitular, MS 123-3-2 (XIV). Both collections contain a prologue in which the author makes it clear that the addressees were the teachers and friars of the Dominican convent in Girona. 
The dominicales collection was designed as a pedagogical tool for a very specific audience of readers: teachers and students. It is a polished edition organised as a complete, practical guide to sermon-making: it comprises sermons for the entire liturgical year, an analytical table (by alphabet) of headings of punctual matters and rhetorical devices applied in specific parts of each sermon, and a table of "moral questions " corresponding to each sermon. The page layout adds to its intended function as a reference tool, as the reader is guided through the parts of the sermons signalled with capitals in the margin, e.g. A, B, etc. These also locate devices in relation to the analytical table, which helped the reader easily find a specific topic or applied rhetorical device in sermons. ${ }^{31}$ Turning to the vernacular elements in the sermons, there are four situations of bilingual alternation: glosses in Catalan, translations or paraphrases of doctrinal matters and of the divisions of the thema, and intrasentential switching. The translation of the divisions is consistently observed in almost all sermons, whereas the other types occur in a few, very specific contexts.

I will first treat the division of the thema since it was essential not only as a structuring device, but also because it had the role of conveying an authoritative, correct, interpretation of the biblical message (the Gospel from which the thema is drawn). The example chosen for illustration is the sermon for the fourteenth Sunday after Trinity, based on the parable of the ten lepers from the Gospel of Luke 17. 11-19: "They stood at a distance and raised their voice saying: Jesus master, have mercy on us " (Luke 17. 13). ${ }^{32}$ So that we can better understand the role of the Latin and vernacular switching in the division of the thema, I will succinctly explain how the sermon unfolds. Nicholas structures the sermon according to the scholastic procedure: a short introduction of the thema and of the broader subject it entails that leads to a moral question (part A) and possible solutions by confronting the authorities, which is the springboard for the deployment of the next section (part B). ${ }^{33}$ Next, he expands on distinctions (parts C; D; E) and subdistinctions (part F) to solve the question raised; once the solution is found, he reiterates the thema and splits it into three parts, in Latin and Catalan. The last part is a moral exposition of the entire gospel passage assigned, like a postil (part G). Returning to the division of the thema, Nicholas breaks it into three sentences mirroring the three syntactic units of the biblical verse, as follows:

31 Colombina y Capitular, MS 123-3-7, the pagination principle is by sermon number written in red ink in the upper right corner of the folio recto. This helped the user of the table to locate the sermon quickly. I will refer to the sermon number and paragraphs (A, B, C, etc.) for references. The applied devices are generally moralitates, similitudes or metaphors. Also note that authorities are indicated in the margin.

32 Colombina y Capitular, MS 123-3-7, Sermon 63, "Dominica post trinitatem xiiij«. I use the Latin Vulgate with the Douay and Rheims version for biblical references. Insofar as it is possible, I aim to stay true to the layout of the manuscript when quoting; I expand silently, when transcribing. All translations are mine, but I am very grateful to Oriol Catalán for his help and clarifications with some of the Catalan sentences in this section. All mistakes are my own.

33 The moral question addressed is: "Volentes bona opera exercere an debeant in publico facere vel occulto (If those who want to do good works should do them in public or in private), in the table of questiones, sermon 63 . The question is formulated at greater length in the sermon. 
"Steterunt a longe et levaverunt vocem dicentes: Jhesu preceptor miserere nostri, Luke 17《.

In quibus tria:

Primo disposicio precedens que est per realem humiliationem "Steterunt a longe«

Secundo execucio accedens que est per verbalem supplicationem "Levaverunt vocem dicentes"

Tercio conclusio sequens que est per totalem remissionem "Jhesu preceptor miserere nostri«

In vulgari

Primo con li devem star cor ab cordial humiliacion

Secundo con li devem parlar cor ab corporal supplicacion

Tercio quen devem reportar cor total remission.

[G] Hec tria patent in evangelio hodierno. Dicatur et post exponatur sic. ${ }^{34}$

The two language blocks are grouped as sets of three verses marked by in vulgari, thus visually delimited on the page. The division of the thema and the maintaining of the rhyme in both languages, within and between the parts of the divisions, is faithfully observed. Nicholas worked with a shared recognisable model of composition which involved translating or rendering the division parts from Latin to the vernacular, which was a common procedure in sermons from other areas. ${ }^{35}$

The Catalan divisions paraphrase the Latin text; they are not literal translations, but an accurate interpretation of the Latin sentences, particularly of the subject of each part, e.g. "disposicio precedens" becomes the clause "con li devem star" in the first part. The technique strongly resonates with what grammar lessons prescribed concerning translation as interpretation and paraphrasing. Moreover, one can observe the employment of semantic meaning over vocal rendition, also a matter I noted in the discussion of advanced bilingual grammars, with which Nicholas' readers were already familiar. ${ }^{36}$ Thus, what Nicholas aimed for was what Yuichi Akae also identified as "actual« or "semantic agreement « between the two languages and not a "verbal agreement « when translating the division of the thema in his study of the model sermon collection of the fourteenth-century English Austin friar John Waldeby. As Akae, like others, argues, the matter of transferring the vernacular from Latin in divisions was crucial because it concerned the "primary interpretation" of the biblical message, not because of the inability to preach in the vernacular to "popular « audiences. Hence, the preachers needed to take "extra care « in this matter and a literal translation (the "verbal

34 Colombina y Capitular, MS 123-3-7, sermon 63, F: "In which words, three things: firstly, the preceding disposition which is by actual humility: They stood at a distance; secondly, the incoming discussion which is by verbal supplication: raised their voice; thirdly, the following conclusion which is by total remission: Jesus master, have mercy on us. In vulgar: Firstly, how we have to stand [be], for it is by genuine humility; secondly, how we have to speak to him, for it is by bodily supplication; thirdly, what we have to report, for it is total remission. Today's gospel is about these three matters; to be said and afterwards explained as such «. »Reportar « in the third Catalan division can be alternatively translated as »to give count«.

35 See for instance the manual of preaching of the Italian Dominican Jacob of Fusignano (d. 1333), who mentions the habit of "modern" preachers of dividing the thema in rhymes - "per quasdam verborum consonancia« and advises that the end of the divisions should end in similar syllables, in Jacobus de Fusignano, Libellus artis predicatorie, ed. and transl. Wenzel, 34-36. See further Wenzel, Medieval Artes Praedicandi, 73, for a convenient synopsis.

36 That preachers did not need to follow the word order in translating from Latin to the vernacular in divisions or thema is also noted by the Pseudo-Aquinas treatise on preaching (late XIV), quoted in Wenzel, Medieval Artes Praedicandi, 45 n. 25. 
agreement «) was unhelpful. ${ }^{37}$ Thus, for preachers who employed the translation of divisions in the vernacular the difficulty consisted not in the vernacular as a language of communication as such, but in how to convey the main scriptural message faithfully without departing from the Latin model. It also explains Nicholas Eymeric's consistent bilingual strategy in the divisions of the thema only.

Yet, the matter of language in the divisions seems obviously related to how the Latin is formulated, as the vernacular depends on that. In our example, the Latin as well as the Catalan seem overly formulaic (unlike the Latin in the body text), but that is because these devices were meant to abstract and synthesize the main message of the sermon. So, there is not only a bilingual switching but also a switch from one level of Latin to another, a rather common occurrence in thematic sermons. Nicholas purposely used these code-switching strategies if we consider the targeted readership and aim of his work: the inexperienced friars could learn how to formulate the biblical message in both languages in a succinct and correct manner. Therefore, the code-switching strategy in the division of the thema in our example cannot be related to a structural function only, since the divisions do not play a role in the development of the sermon, as the B type of bilingualism would work in Wenzel's categorisation. For when we look at the division and its place within the sermon structure, we see that it occupies a transitional position between the solution to the question raised and the exposition of the gospel. In this sermon, it is the moral question that plays the leading role in structuring the discourse, not the division of the thema, which betrays the didactical origin and purpose of the work. Nicholas' structuring strategy is rather unusual, since most sermon authors and practising preachers who employed the division of the biblical verse placed it either after the introduction of the thema or immediately after assuming the thema. In this case, the role of the thematic division in the entire discourse is to conclude the truth demonstrated in the development of the sermon. Thus, translation of the divisions only was prioritised because they encapsulate the very essence of the biblical verse and of the moral lesson the sermon aimed to teach: what we should do and how. The moral exposition of the gospel that closes the sermon serves as a recapitulation and reinforcement of that moral lesson. To sum up, bilingual code-switching in the thematic division in this example is a deliberate, conscious strategy because it concerned an authoritative interpretation of the Bible. Hence, it could not be left to chance or the inspiration of the moment, particularly for the untrained preachers. The translation of the division could be used by Nicholas' intended readers no matter how they structured their sermon: they could use the sermon as it was, rearrange the different parts, or leave out what they deemed unnecessary for their purpose or public, whether they were to preach it in Latin or Catalan.

37 Akae, Mendicant Sermon Collection, 206-225, for the discussion of language; on the distinction between concordatia vocalis (verbal agreement) and concordatia realis ("actual« or »sematic agreement«), as prescribed by John's contemporary Robert Basevorn, ibid., 207. I am very grateful to Dr. Akae for generously providing me with a copy of his book. On the exegetical importance of the divisions as the main reason why they are translated in bilingual sermons from France, see also Bériou, Latin et langues vernaculaires, 197. 
A similar concern with how to interpret and articulate a doctrinal message concisely and correctly emerges from the second example of bilingual alternation in Nicholas Eymeric's collection. The switch occurs in one of the main parts (division) of a sermon for the first Sunday of Advent, in which Nicholas speaks of the condition of the postlapsarian man, the fall from grace and the necessity of Christ's coming, the main subject of the sermon. In this case also, bilingual code-switching does not play a structural role but is employed strategically and deliberately in the discussion of important doctrinal points as seven »difficulties « faced by man to placate God after the fall and liberate himself. The "difficulties" are presented in two separate blocks as verses, in Latin first and Catalan second, marked by "vulgariter sic". As in the previous example, the Catalan version does not follow the Latin literally, but paraphrases it and exhibits the same preoccupation with staying close to the meaning of the Latin verses, as in the first and sixth distinctions (arbitrarily chosen for illustration):

Primum sigillum et difficultas erat demonis subiectio, quia homo erat a demone devictus et servus factus.

Primer segell o difficultat quel diable havia lo humanal linatge vensut e captivat. ${ }^{38}$

Sextum gracie privatio quia erat amore divino frustratus.

VIm que per tal Deu lo para de la sua amor e gracia lavia privat. ${ }^{39}$

Nicholas' main aim here is to provide models of composition of important doctrinal material in both languages with attention to the stylistic effect created by rhyme. Besides, the seven-line "poems" could be fleshed out accordingly when preaching in different venues. They could be readily reused as self-contained texts outside this context and applied to specific needs.

The third kind of bilingual switch in Nicholas' sermon manual is a common occurrence in late medieval sermons: glosses inserted within the Latin sentence as an aid to readers in search of a precise word in the vernacular, and as a wordplay on etymology, respectively. The former is encountered in the sermon for the Septuagesima Sunday, in a list of five forms of avarice. He only translates the third and the fourth varieties - fraud and deceit, perhaps to make clear the distinction between intention and action presupposed by each, or to suggest how to best render them in Romance: "fraus, id est ganyonia in cogitatione (fraud, i.e. stinginess in thinking), and "fallacia, id est traydoria in tractatu et commutatione" (deceit, i.e. treachery in dealing and exchanging).$^{40}$ The latter example is an explanation of a word in Catalan by etymology in the manner of a gloss and occurs in a sermon for the Passion Sunday (before Palm Sunday) in the discussion of the lustful (»luxuriosi«): they are called »anamorats" (»enamoured" or »infatuated «) in the common tongue, because they are »orats" (»cra$\mathrm{zy}$ « or "fools«) when in love (»et ideo vocantur vulgariter anamorats quia in amore orats «). ${ }^{41}$ As we can see, the bilingual switch here can be considered intrasentential.

38 Colombina y Capitular, MS 123-3-7, »Sermo primus de adventu domini«, sermon 1, H: »The first seal and difficulty is that he was under the subjugation of the devil, for the man was defeated by the devil and enslaved «. Catalan: "The first seal or difficulty [is that] the devil defeated and captured the human lineage".

39 Colombina y Capitular, MS 123-3-7, sermon 1, H: »The sixth [is] privation of grace, for he was robbed of the divine love«. Catalan: "The sixth [is] that, as such, God the Father deprived him of his love and grace».

40 Colombina y Capitular, MS 123-3-7, "Dominica in lxx«, sermon 18, D.

41 Colombina y Capitular, MS 123-3-7, »Dominica in passione«, sermon 25, E. 
Intrasentential code-switching is more clearly illustrated in Nicholas' sermon for Good Friday. Why in this sermon and not in others in the collection is also a deliberate decision on the part of the author, as it concerned a liturgical occasion with a particular emotional impact. Like other late medieval preachers, Nicholas used vernacular intermingling in this altogether dramatic sermon to help recreate the ominous events of Christ's capture, judgment and crucifixion. ${ }^{42}$ The bilingual intermingling (type $\mathrm{C}$ in Wenzel's taxonomy) is, however, not random or inordinate, but well thought through since it appears in contexts centred on Mary and is meant to convey a mother's grief and distress through the use of vernacular terms (adjectives and nouns) that express sorrow. More precisely, the switch comes up in describing Mary's utter loss and lamentation, as well as in dialogues or direct speech:

"Ecce quantum infortunium, quanta mala ventura, quant desastre li ha vengut! Ecce modo est mulier desavneturada, dona desmaridada, mara molt dolorosa, virge molt amargosa $\ll ; 3$

when John arrives with news of Jesus' trial and impending crucifixion and Mary's reaction, respectively:

»Heu me miser! Heu me las! Heu me dolent e esmarrit! quid faciam?«

"O marrida, o dolenta, ubi habetis infantem meum? O lassa despagada e mesquina, ubi

habetis bone Johannes magistrum vestrum Ihesum?«; ${ }^{44}$

and in Mary's lament at the sight of her son on the via crucis:

„O misera, quid faciam? O despagada, quid dicam? O dolenta, quo sine filio meo pergam? « ${ }^{45}$

Therefore, Nicholas' decision in this instance was tied to a liturgical occasion that required drama and a sense of alertness to retell the story of the Passion in which potential audiences could partake emotionally. His strategy was also rhetorical because the sermon is structured very differently from the rest in the collection: it is mostly an exposition of the gospel. Furthermore, this sermon is also an illustration that the mixing of all types, particularly

42 Colombina y Capitular, MS 123-3-7, "Primus sermo in feria sexta parasceve«, sermon 28. This type of mixing in sermons for Good Friday and Resurrection Sunday can be encountered in France, Italy or England from the thirteenth through the fifteenth centuries, and scholars generally explain it as a sign that the vernacular as mother tongue was more suitable for capturing and expressing deep emotion; see Wenzel, Macaronic Sermons, 66-67; Bériou, Latin et langues vernaculaires, 201; Delcorno, Language of the preachers, 57-59 (a discussion of language mixing in a Passion sermon by a Dominican); Johnson, Grammar of Good Friday.

43 Colombina y Capitular, MS 123-3-7, sermon 28, A: "Behold what misfortune, what bad luck, what a disaster came upon her! In this way she is an unfortunate woman, separated lady, very sorrowful mother, very bitter virgin«.

44 Colombina y Capitular, MS 123-3-7, sermon 28, H: „Alas miserable me! Alas poor me! Alas sorrowful and desperate me! What will I do?«, and Mary: »Oh, wife, oh, sorrowful [woman], where do you have my child? Oh, poor, unconsoled and unlucky [woman], where do you have your master Jesus, good John?«.

45 Colombina y Capitular, MS 123-3-7, sermon 28, H: »Oh miserable me, what will I do? Oh wretched me, what should I say? Oh sorrowful me, how shall I go on without my son?«. Further on, language mixing occurs briefly when Mary addresses Mary Magdalen: »O molt amada filii mei« (»Oh, much beloved to my son!«). 
$\mathrm{C}$, was not necessarily random or uncommon in ready-made editions of sermons. Overall, Nicholas Eymerich's collection demonstrates that bilingualism was a conscious written strategy of authors and preachers who sought to offer models of interpretation and translation for preachers-in-training.

Nicholas's collection is but one example of the many editions of ready-made sermons rooted in a pedagogical context that can be encountered in other areas in the Late Middle Ages. Yet, bilingual code-switching in sermons as a written convention is not necessarily specific to editions or didactical contexts, but often features in types of texts and manuscripts for personal use. A case in point is the next example of a manuscript with sermon drafts by Guillelmus Simonis (d. 1365), another Dominican preacher from the convent of Girona and a contemporary of Nicholas Eymeric.

Guillelmus was one of the more ordinary Dominican preachers and teachers, whose less glamorous yet essential contribution to the Dominican preaching body and wider audiences was through teaching at the lower levels (logic, theology lectures in the schola) and preaching. ${ }^{46}$ Guillelmus wrote a collection of Sunday sermons for the summer and autumn season (1358) which is preserved in a manuscript in Seville, my present focus, and in three other fourteenth- and fifteenth-century codices currently held in other European libraries. The Seville codex, very likely the earliest witness of Guillelmus' sermons, is a small, portable (15.5 $\mathrm{x} 12 \mathrm{~cm}$ ), paper book for personal use. There are reasons to believe that the book was a work in progress (perhaps an autograph), since many of the sermons are incomplete, with space left to fill in later, e.g. structural parts, entire paragraphs cancelled (struck out or indicated as "vacat «), cross-references to other sermons in the collection, and notes to oneself and potential readers, e.g. "apply and conclude «. ${ }^{47}$ Possibly, the author intended to create an edition based on his actual preaching and teaching in the convent schola, as was often the case with sermon collections, and that edition probably materialised in light of several other witnesses. Concerning bilingual insertions, Guillelmus' sermons contain several examples of linguistic alternation and intermingling of all types: structural and illustrative elements, and some that can qualify as intersentential switches.

The only example of bilingual code-switching in the division of the thema is in a sermon for the fourteenth Sunday after Trinity drawn from the gospel of the day (Luke 17) on the ten lepers, which allows for a comparison with Nicholas' sermon for the same occasion. Compared to Nicholas, Guillelmus has a more "classical« approach to the thematic sermon and his sermons are generally more instructive than argumentative, thus much closer to what one was expected to preach to a general public. As I proceeded with Nicholas, I shall first give a

46 See the short biography in Kaeppeli, Scriptores 2, 163. It does not seem he ever studied in a general studium, but became Preacher General late in his career.

47 Guillelmus Simonis, Sermones dominicales (1358) in Sevilla, Capitular y Colombina MS 59-3-7 (XIV), as Sermones de tempore. I take the title dominicales from the explicit: "Expliciunt sermones dominicales de primo opere per ffratrem Guillelmum Simonis ordinis predicatorum compilati anno domini 1358«. The manuscript was in the personal collection of an archbishop of Seville in 1397. It contains a table of pericopes for Sunday sermons, several lines of theological notes, 54 sermons, and medical recipes by the author and by a later hand that adds more recipes for ear ailments on the flyleaf. The other manuscripts are in the Czech Republic and France: Kynžvart 20 H 13 (XIV); Třeboň, State Archive A2o (XV); Strasbourg, Bibliothèque Nationale et Universitaire 100 (XV). None has been studied, to my knowledge. 
very brief overview of the structure of the sermon. From the verse »They raised their voice saying: Jesus master have mercy on us", the preacher briefly introduces the thema and focuses on sins as incurable diseases by nature to make the point that all need to ask for divine mercy to be cured. Next, he breaks the thema into four parts, followed by distinctions based on the fourth part only and then subdistinctions. The last part of the sermon, which is not elaborated upon, but indicated, would be a literal exposition of the gospel: "Hic narra ystoriam evangelii solum ad litteram ad prolixitatem vitandam et postea fac finem ${ }^{48}{ }^{48}$ The fourfold division of the thema is first given in Catalan and then in Latin, as follows:

Levaverunt vocem dicentes Ihesu preceptor miserere nostri, Lk. [Luke 17. 13]

In quibus verbis, scilicet per ordinem, ostenduntur [sic] isti leprosi:

Primo la lur voluntat a fervor de devocio provocaren "Levaverunt voem «4

Secundo lo gran poder de deu regonegueren e conffessaren "Dicentes: Ihesu preceptor"

Tercio merce e misericordia humilment li demanaren "miserere nostri"

Quarto tangitur la rahon sufficient quali allegaren "quia viri leprosi«

Primo quia affectum ad devocionem provocaverunt »Levaverunt vocem «

Secundo divinam potenciam recognoverunt »dicentes Ihesu preceptor«

Tercio eius pietatem et misericordiam postulaverunt »miserere nostri«

Quarto causam quam sibi allegaverunt $\Perp$ decem viri leprosi巛. ${ }^{49}$

The division of the thema and the two languages visually stand out from the rest of the sermon, as separate verses, which Guillelmus employs throughout the book. Stylistically, the author is attentive to the rhyme at the end of the four verses, which falls on the verb in both languages. Also, the attention to sematic rather than verbal interpretation in language alternation is evident and the Latin version is more contracted than the Catalan, like a paraphrase. The issue is whether Guillelmus translated or adapted the Latin from the Catalan, which comes first, which might imply that he conceived the Catalan verses first. While hard to tell, it might reveal something of the workings of a »bilingual mind« trained to use both languages actively and with a solid level of theological literacy, as I suggest in the discussion of Dominican language training. ${ }^{50}$ Compared to Nicholas's sermon for the same occasion, there is a noticeable difference between how the two preachers formulated the divisions in order to convey the essential subject of the sermon. That rests on the decision each made about what they sought to inculcate, their respective purpose and the structuring method..$^{1}$

48 Capitular y Colombina MS 59-3-7, Sermon for the 14th Sunday after Trinity, fols. 90v-93v: "Here tell the story of the gospel only literally to avoid verbosity and end afterwards".

49 Capitular y Colombina MS 59-3-7, fol. 91v, the underlining and the stricken out word in the manuscript: "In which words, that is, in order, these lepers showed: firstly, they summoned their will to the fervour of devotion: sthey raised their voice'; secondly, they recognised and confessed the great power of God: ssaying Jesus master<; thirdly, they humbly asked for his pity and mercy: have mercy on us<; fourthly, to mention the sufficient reason they laid before him: in the words sten lepers «; Latin: "firstly, they stimulated their disposition to devotion: sthey raised their voice<; secondly, they recognised the divine potency: ssaying Jesus master«; thirdly, they asked for his pity and mercy: 'have mercy on us`; fourthly, the reason they pleaded with him: sten men with leprosy«".

50 One also wonders why the switch only occurs in this sermon and not in others; one thought is that perhaps the author worked with other drafts or that the vernacular simply came to mind first.

51 The comparison stands for the rest of the sermons by the two authors; here I only point it out because Guillelmus employs bilingual alternation. 
Nicholas sought to answer a question around which he organised the entire discourse, and the division functioned as a confirmation or conclusion of what he intended to prove; Guillelmus focused on a single issue - leprosy as sin - and the division was meant to capture that message. Thus, despite the difference in emphasis between the two authors, the importance of the division in their sermons is both methodological and interpretive and adds to the point made about the formulating of divisions and of further rendering them in either language. Last, the employment of the gospel exposition as a structural part of the sermon by both preachers serves as a further reinforcement of the sermon's message..$^{52}$

Other instances of bilingual code-switching in Guillelmus Simonis's sermon drafts only appear in two sermons for Pentecost, whose themata are drawn from the Psalms. In both sermons, Guillelmus employs a vernacular proverb as a method of introducing the thema and of setting the overall focus of the sermon, thus playing a double role - rhetorical and structural. In the first example, Guillelmus announces the thema and immediately places the proverb after it:

"Spiritus tuus bonus deducit te in terram eternam«. Ps. Vulgariter qui dicitur qui deu anar en altra region se deu guarnir de bon companyon..$^{53}$

The proverb opens a brief discussion about why one needs a good companion when travelling far from home, i.e. paradise; hence, one needs the company of the Holy Spirit in the earthly voyage. The discussion ends with the reiteration of the proverb in Latin: „Ergo qui vult ire in longicam regionem debet habere bonum ductorem « (Therefore, whoever wants to go to a distant region must have a good guide). Thus, the preacher's motive of writing down the proverb in Catalan, which he translates pretty much literally in Latin, was not only the desire to record it as such because it made sense to his "popular" publics, but also because the proverb had a functional role in his discourse. ${ }^{54}$

The same remarks are valid for the other example of a proverb inserted after the thema in the last sermon of the collection. The Catalan proverb is rendered in Latin more or less literally in bilingual alternation. It too functions as a means to introduce the subject and is reiterated in Latin at the end of the introduction. As in the other sermon for Pentecost, it is another example of local wisdom the preacher picked up and thought worthy of preserving in writing and useful for making a larger point:

52 One may wonder whether it was a local custom of the preachers in Girona to integrate the gospel exposition in a scholastic sermon; only further systematic research will enable us to answer that.

53 Colombina y Capitular, MS 59-3-7, »De spiritu sancto « (»in festo Pentescotis [sic] «, added by the same hand at the top of the page), fols. 57v-61v: "Your good spirit leads me to the eternal land. Psalm 142.10. It is said in the spoken language: Who has to go to another region needs to guard oneself with a good companion".

54 For a similar position on the function of proverbs in thirteenth-century sermons, see Morenzoni, Proverbes dans la prédication, especially $132-133$. 
„Flavit spiritus eius et fluent aque«, Ps. Vulgariter: Infant epeys ayga crex. Litteraliter: pisces et infantes in aquis sunt crescentes..$^{55}$

From the standpoint of language, the sermon is also relevant because the switch is not only bilingual but between discursive strategies: a switch to direct speech (in Catalan) within sentences and the use of Catalan for emphasising an argument. Such switches occur in almost every division of the sermon as sayings, jokes or simply expressions in the vernacular, which the author did not feel the need to translate. For instance, in the first division, expounding on the term "fire" as inordinate passion (which the Holy Spirit extinguishes), Guillelmus discusses heat and burning as a penalty for avarice, applied to the rich man in hell from the parable of Lazarus in Luke 16. 19-31. He narrates the plea of the rich man who was burning in hell and rebukes him in Catalan:

\section{[...] quia crucior in hac flamma. Isti dicendum est: si es calt buffa ho. ${ }^{56}$}

Guillelmus also employs a vernacular expression ("proverbium vulgare«) as illustration in yet another sub-division: "tan trona enceo que plou" (»it thunders so much in the sky that it rains «). ${ }^{57}$ Lastly, the author either renders sentences from Latin into Catalan for emphasis or uses a Catalan sentence as a bridge for the next section:

Ideo combustit se in hoc mundo et postea in inferno. Vulgariter: aci hac calor e en infern se crema. ${ }^{8}$

Escalfar ques crema. Et quia istum amorem non fugit dives ideo se eombussit ideo credens se calefacere se combussit combustus fuit. ${ }^{59}$

The two case studies demonstrate that bilingual code-switching in sermons as a written phenomenon was embedded in an educational and intellectual context and in a set of conventions in composing sermons. That one is an edition of ready-made sermons and the other a draft further proves that bilingualism was an internalised habit and working method for Aragonese Dominican authors. Thus, it cannot be reduced to a particular kind of text and

55 Colombina y Capitular, MS 59-3-7, fols. 168r-172v: ")His wind blows and waters shall run<, Psalm 174, 18. In vulgar: $a$ child and a fish grow in water. Literally: children and fish grow up in water«. As Guillelmus explains, children, like fish, need to be bathed and nursed in order to grow; in this case, the Holy Spirit is the water that nurtures and cleanses the faithful.

56 Colombina y Capitular, MS 59-3-7, fol. 168v: "[...] for I am tortured in this fire. To these people we should tell: if it is hot, blow on it!«. Further down the same page, there is another example that mimics direct speech: "Ideo dicitur vulgariter que tal se cuyda?«, that is "That is why they say in vulgar: how does he take care of himself?».

57 Colombina y Capitular, MS 59-3-7, fol. 169v; the sentence before also contains bilingual alternation as direct speech: "cogita a tu; ho dic fila enten ho tu nena", that is "think about it; I say daughter understand it by yourself, girl .

58 Colombina y Capitular, MS 59-3-7, fol. 168v: "He burns in this world and afterwards in hell. In vulgar: He is hot here and in hell he burns".

59 Colombina y Capitular, MS 59-3-7, fol. 169r: "Heating until he burns. And because the rich man did not flee from this passion, he therefore burnt himself, therefore believing that he warmed himself he burnt he got burnt«. 
immediate audience. The bilingual alternation in the structural elements, particularly the division of the thema, is so often present in texts at whatever stage of composition because they were central in the discourse or to the potential discourse one would preach based on the predominantly Latin text. ${ }^{60}$ Both cases also show that translating as such was not the main issue but the formulating of the focus of sermon contained in the biblical message of the text.

Bilingualism of all kinds as a written strategy was common practice in the sermons of preachers of any affiliation in the Catalano-Aragonese area. The evidence from the early fourteenth through the early fifteenth century shows that writing down structural devices in both Latin and the vernacular or only in the vernacular, as well as glosses and proverbs, was a widespread habit. They can be found in sermons composed by Franciscan or anonymous authors, »editors « or scribes. Examples of this were reference works, products of preaching and editorial decisions taken by those who wrote and further transmitted texts for others to use. ${ }^{61}$

If we go further on towards the late fourteenth century, we notice that Catalan preachers continued to write their sermons in Latin with structuring devices in Romance and in mixtures of apparently random types, either for personal use or for larger audiences. One such example is a likely personal, minute manuscript of a late fourteenth-century anonymous preacher.$^{62}$ The sermons contain a number of bilingual code-switching strategies similar to Guillelmus Simonis's collection, thus reinforcing that these bilingual written practices and composition techniques were common in the area. Code-switching occurs, for instance, in the division of the thema, in the use of vernacular proverbs as functional elements, or in the intrasentential type of switching. Take, for instance, the division of the thema in a sermon for the Resurrection Sunday, which shows that the way the Latin is formulated can make a literal or mostly literal translation easy:

60 Certainly, this habit might have worked differently in other areas; Delcorno, Language of the preachers, 52, for instance, points out that linguistic alternation in divisions was not very common in fourteenth-century sermons from Italy.

61 For instance, the Franciscan Bernard of Deo's collection of sermon outlines integrated in his work Summa predicabilium (1318), in Tarragona, Biblioteca Pública del Estado, MS 127 (XIV). The bilingual situations are either Catalan translations of Latin verses, distinctions or subdistinctions, or Catalan words/phrases reiterated and explained in Latin; see fol. 7ra, fol. 9v, fol. 23v, fol. 26r, fol. 30v. Another example is Prince Juan of Aragon (d. 1334), Archbishop of Tarragona, whose sermons were collected, redacted and edited after his death in a manuscript from around 1350. A number of these sermons contain structural devices (divisions, distinctions), proverbs or glosses in Catalan and Castilian, occasionally in Latin-vernacular alternation, in Valencia, Cathedral Library, MS 182 (XIV). My thanks to Oriol Catalán for sharing his copies with me.

62 ACA, Ripoll, MS 223 (XIV-XV), sermons on fols. 144r-223r. 
»[E]n vivit filius tuus « [John 4.50].

Primo, Christi resurectio publicata: »en«; secundo, suis mors in vitam comutata: »vivit«; tercio, mater consolatio magna data: "filius tuus«. Primo, la sia resurecio es manifestada, publicada, quia "en «; secundo, la sia mort en vida es tornada; tercio, ala sua mayora consolacio es dada. ${ }^{63}$

Intrasentential code-switching occurs in the same sermon, which confirms that codeswitching in sermons on the Passion and Resurrection was common currency:

[...] illam tunicam talem polimiticam quam virgo mater ei fecerat, scilicet corpus filii sui preciosi, totaliter lanjaverunt et totum fregerunt in tantum quod no si tenia pinzola. $^{64}$

Quia re vera non est in mundo pus vil pellus (...) quam miserabile corpus. ${ }^{65}$

This example is probably just one among many others that still remain undiscovered in the area of my focus. As further evidence suggests, preachers in late medieval Catalonia continued to work within this longstanding writing tradition. There is certainly more diversity of written sermon texts in terms of linguistic intermingling and alternation than in the previous period. However, a general view of sermons written during this period in Aragon indicates that authorities and structural elements remained standard features of bilingualism, regardless of the language of composition or redaction. Latin sermons or sermon outlines with divisions, distinctions and subdistinctions in the vernacular or the other way round, i.e. a vernacular sermon with structural elements in Latin, coexisted in the same manuscript. ${ }^{66}$

63 ACA, Ripoll, MS 223, fol. 216v. Translation: »Behold, your son lives«. Firstly, the resurrection of Christ is published: »behold «; secondly, his death is changed to life: "he lives«; thirdly, great consolation is given to the mother: "your son". Firstly, his resurrection is made manifest, public, in the word »behold «; secondly, his death is turned into life; thirdly, to her great consolation it is given «. Another example of bilingual division of the thema in this collection is in a Trinity sermon, fols. 220v-23v, which also contains a vernacular word inserted within the text and translated in Latin afterwards, at fol. 221r. A proverb with the role of introducing the thema comes in a sermon for Corpus Christi, fols. $212 \mathrm{v}-216 \mathrm{v}$, and occasions a short discussion of friendship as self-sacrifice: "'Accipite et manducate, hoc est corpus meus`. Mt. XVII. Quamvis amici comunicent in vicem sibi bona sua liberaliter, vulgariter: $S a$ habandona tot so qui an la .i. a altro" ("Take and eat, this is my body", Matthew 26. 26. "Friends ever so often share each other's things liberally«; in vulgar: "They abandon all they have to one another«).

64 ACA, Ripoll, MS 223, fol. 217v: »they totally tore to pieces and broke it whole that tunic so colourful, i.e. the body of her precious son, which Virgin the mother made for him, so much that there was no shred (?) left". I have not been able to identify the word "pinzola«; from the context, I tentatively translate it as "shred«, a piece of cloth/rag.

65 ACA, Ripoll, MS 223, fol. 218r: »For actually that there is no cover more worthless in this world (...) than the miserable body«. The ellipsis stands for a Catalan phrase which I have not been able to clarify on this occasion; that shall also remain a task for the future.

66 For sermons in Catalan as a matrix language, see Catalán Casanova, forthcoming, in this journal. 
Latin still remained the preferred language of writing sermons, although the backbone of the discourse started to be composed only in the vernacular more often than before, or so it appears in the available evidence. ${ }^{67}$ Thus, divisions, distinctions and other subunits of sermons only in Catalan appear to be distinctive features of many sermons from the early fifteenth century, which might indicate a shift in editorial and writing fashions and possibly a change in the status of the vernacular as a written language for theological discourse. Another explanation for the dropping of Latin divisions could also be that preachers no longer saw it as necessary to have the Latin version for guidance and that the vernacular served them just as well when preaching in either language. When authors did give an alternative bilingual division, they likely meant to offer guides of interpretation for other users or to keep their options open for various preaching circumstances.

Although this paper focused on Dominican examples in the Catalan area, bilingualism as a written convention was a shared practice of preachers from elsewhere, such as England, Italy or France. My suggestion about code-switching in Latin sermons as originating in a bilingual educational setting and further applied to a particular type of theological discourse might not explain everything or might not be applicable to other areas in the same manner. Nonetheless, Dominicans in Aragon, like other mendicants and scholars, were part of larger European and regional intellectual networks, hence the similarities in methods of composing bilingual sermons in texts from elsewhere. Yet, to understand patterns of bilingual mixing and alternation in sermons and why certain types were more common in some areas and not in others, we need a broader comparative perspective that includes approaching multilingualism as a phenomenon beyond texts meant to be uttered and beyond genres in isolation. The first step, in my view, is unearthing sermon manuscripts that lay unstudied because they do not correspond to our linguistic criteria - either Latin or the vernacular.

\section{Acknowledgements}

This work was supported by the Austrian Research Fund (FWF), project M 2701-G (20192021). Previous research on some of the archival sources was partially funded by the Government of Spain, project FFI2015-63659-C2-2-P, MINECO/FEDER, EU (2016-2019). I am grateful to Jan Odstrčilík for comments on an earlier version of this article. I also thank the two anonymous peer reviewers for their suggestions and comments.

67 Dominican examples of sermons in which structural devices are in the vernacular: Barcelona, Biblioteca de Catalunya, MS 479 (XV), unitary manuscript of an anonymous Dominican, likely a teacher; see Catalán Casanova, Predicació cristiana, 298-300, for a discussion; editions of seven sermons at 439-484. Another example is a sermon by the Dominican Antoni Canals (d. 1418), whose sermon (preached in the Dominican convent in Valencia) was very likely edited later and preserved in a fifteenth-century manuscript; see Wittlin, Sermón en latin, 295-302. Also, sermons of the Aragonese Dominican Sancho Porta (d. 1423) exhibit a variety of bilingual strategies, in Valencia, Cathedral Library, MS 244 (XV). 


\section{References}

Abbreviations

ACA = Arxiu de la Corona d' Aragó

PARES $=$ Portal de Archivos Españoles .

\section{Manuscripts}

Barcelona, ACA, Ripoll, MS 79.

Barcelona, ACA, Ripoll, MS 97.

Barcelona, ACA, Ripoll, MS 123.

Barcelona, ACA, Ripoll, MS 139.

Barcelona, ACA, Ripoll, MS 142.

Barcelona, ACA, Ripoll, MS 147.

Barcelona, ACA, Ripoll, MS 153.

Barcelona, ACA, Ripoll, MS 154.

Barcelona, ACA, Ripoll, MS 184.

Barcelona, ACA, Ripoll, MS 191.

Barcelona, ACA, Ripoll, MS 223. Available at PARES. Retrieved on 30 October 2020: http://pares.mcu.es/ParesBusquedas/servlets/Control_servlet?accion=3\&txt_id_desc_ $\mathrm{ud}=2381132 \&$ fromagenda $=\mathrm{N}$.

Barcelona, Biblioteca de Catalunya, MS 479.

Sevilla, Capitular y Colombina, MS 59-3-7.

Sevilla, Colombina y Capitular, MS 123-3-7.

Sevilla, Colombina y Capitular, MS 123-3-2.

Tarragona, Biblioteca Pública del Estado, MS 127. Available through Biblioteca Virtual de Patrimonio Bibliográfico. Retrieved on 30 October 2020: http://bvpb.mcu.es/es/consulta/ registro.do?id $=397190$.

Valencia, Cathedral Library, MS 182.

Valencia, Cathedral Library, MS 244.

Zaragoza, Bilioteca Universitaria, MS 185.

\section{Edited Sources}

Acta capitulorum generalium Ordinis Praedicatorum 2, ed. Benedictus Maria Reichert (Rome, 1899).

Jacobus de Fusignano, Libellus artis predicatorie, ed. and transl. Siegfried Wenzel, The Art of Preaching: Five Medieval Texts and Translations (Washington, DC, 2013) 3-95.

Johannes de Mena, Chronicon breviusculum fratris Ioannis de Mena ab anno MCCCLXVI ad MCCCLXXXVIII, ed. José Hinojosa Montalvo (Valencia, 1975).

Kaeppeli, Thomas, Dominicana Barcinonensia: Asignationes librorum, professiones novitiorum (s. XIII-XV), Archivum Fratrum Praedicatorum 37 (1967) 47-117.

Petrus de Arenys, Chronicon, ed. José Hinojosa Montalvo (Valencia, 1975).

Wittlin, Curt, Un sermón en latin de fray Antoni Canals, hecho en Valencia el 8 de setiembre 1392: La Virgen María, un libro, Escritos del Vedat 27 (1997) 286-302. 


\section{Secondary Literature}

Akae, Yuichi, A Mendicant Sermon Collection from Composition to Reception: The Novum opus dominicale of John Waldeby, OESA (Turnhout, 2015).

Bériou, Nicole, Latin et langue vernaculaire dans les traces écrites de la parole vive de prédicateurs (XIIIe-XIVe siècles), in: Stéphanie Le Briz and Géraldine Veysseyre (eds.), Approches du bilinguisme latin-français au Moyen Âge: Linguistique, codicologie, esthetique (Turnhout, 2010) 191-206.

Bériou, Nicole, Les sermons latins après 1200, in: Beverly Mayne Kienzle (ed.), The Sermon (Turnhout, 2000) 363-447.

Calvo Fernández, Vicente, Una gramática latina medieval con notas en romance castellano, Cuadernos de Filología Clasica: Estudios Latinos 2 (1992) 249-261.

Catalán Casanova, Oriol, La predicació cristiana a la Catalunya baixmedieval: Un instrument de transformació cultural entre oralitat, escriptura, imatge, naracció, música i teatre. Unpublished PhD thesis (University of Barcelona, 2013). Retrieved on 23 October 2020: hdl. handle.net/2445/44991.

Copeland, Rita and Ineke Sluiter (eds.), Medieval Grammar and Rhetoric: Language Arts and Literary Theory, $A D$ 300-1475 (Oxford, 2012).

D’Avray, David, The Preaching of the Friars: Sermons Diffused from Paris before 1300 (Oxford, 1985).

Delcorno, Carlo, The language of the preachers: Between Latin and vernacular, The Italianist 15 (1995) 48-66.

Esparza Torres, Miguel Ángel and Vicente Calvo Fernández, La Grammatica proverbiandi y la Nova ratio Nebrissensis, in: E. F. K. Koerner and Hans-Josef Niedrehe (eds.), History of Linguistics in Spain 2 (Amsterdam, 2001) 35-56.

Fletcher, Alan, Written versus spoken macaronic discourse in late medieval England: The view from the pulpit, in: Judith A. Jefferson and Ad Putter (eds.), Multilingualism in Medieval Britain (c. 1066-1520): Sources and Analysis (Turnhout, 2013) 137-152.

Heimann, Claudia, Nicolaus Eymerich (vor 1320-1399): Praedicator veridicus, inquisitor intrepidus, doctor egregius. Leben und Werk eines Inquisitors (Münster, 2001).

Johnson, Holly, The Grammar of Good Friday: Macaronic Sermons from Late Medieval England (Turnhout, 2012).

Kaeppeli, Thomas, Scriptores Ordinis Praedicatorum Medii Aevi 2 (Rome, 1975).

Kienzle, Beverly Mayne (ed.), The Sermon (Turnhout, 2000).

Maierù, Alfonso, Dominican Studia in Spain, in: Kent Emery, William J. Courtenay and Stephen M. Metzger (eds.), Philosophy and Theology in the Studia of the Religious Orders and at Papal and Royal Courts (Turnhout, 2012) 3-31.

Morenzoni, Franco, Les proverbes dans la prédication du XIIIe siècle, in: Hugo O. Bizzari and Martin Rhode (eds.), Tradition de proverbes et des exempla dans l'Occident médiéval/Die Tradition der Sprachwörten und exempla im Mittelalter (Berlin, 2009) 131-149.

Muessig, Carolyn, The vernacularization of late medieval sermons: Some French and Italian examples, in: Christopher Kleinhenz and Keith Busby (eds.), Medieval Multilingualism: The Francophone World and its Neighbours (Turnhout, 2010) 267-284.

Mulchahey, Michèle, "First the Bow is Bent in Study«: Dominican Education before 1350 (Toronto, 1998).

Negoi, Lidia, Dominicans, Manuscripts, and Preaching in Medieval Aragon (XIV): A Social History of Communication. Unpublished $\mathrm{PhD}$ thesis (University of Bergen, 2016). 
Roest, Bert, A History of Franciscan Education (c. 1210-1517) (Leiden, 2000).

Rosier-Catach, Irène, Grammar, in: Robert Pasnau and Christina van Dyke (eds.), The Cambridge History of Medieval Philosophy 1 (Cambridge, 2010) 196-216.

Schendl, Herbert, Code-switching in late medieval macaronic sermons, in: Judith A. Jefferson and Ad Putter (eds.), Multilingualism in Medieval Britain (c. 1066-1520): Sources and Analysis (Turnhout, 2013) 153-170.

Schendl, Herbert and Laura Wright, Code-switching in early English: Historical background and methodological and theoretical issues, in: Herbert Schendl and Laura Wright (eds.), Code-switching in Early English (Berlin, 2011) 15-46.

Thayer, Anne T., Medieval sermon studies since The Sermon: A deepening and broadening field, Medieval Sermon Studies 58 (2014) 10-27.

Wenzel, Siegfried, Macaronic Sermons: Bilingualism and Preaching in Late Medieval England (Ann Arbor, 1994).

Wenzel, Siegfried, Medieval Artes Praedicandi: A Synthesis of Scholastic Sermon Structure (Toronto, 2015). 